\title{
Why Is the Target of Human Development Index Hard to Be Achieved? An Analysis of the Strategic Environment
}

\author{
Iis Sandra Yanti \\ Institut Pemerintahan Dalam Negeri
}

Received: Oct. 13, 2020 Accepted: Oct. 27, 2020 Online published: Dec. 30, 2020

doi:10.5296/jpag.v10i4.17819 URL: https://doi.org/10.5296/jpag.v10i4.17819

\begin{abstract}
Human Development Index (HDI) is still used for determining the quality of human life in local government. In local government, specially in industrial region, HDI is to hard to be achieved. Bekasi regency as the biggest industrial region of the South-East Asia also has same problem about achieving HDI target annually. With qualitative method, this research tries to identify factors that causing HDI target of Bekasi Regency is not achieved in 2012-2017 period. Some results shows that the factors are natural environment, social environment, and task environment.
\end{abstract}

Keywords: human development index, environmental scanning, local government, local development

\section{Introduction}

In recent years, the issue of the achievement of public welfare has become a concern of government administrators. Since Indonesia's independence was proclaimed until the current reform era, various development planning policies both at the national and regional levels have paid special attention to the achievement of community welfare. This is undeniable considering that people's welfare is a measure of the success of a country's development.

From time to time, the government's attention, including the power elites, academics, and political observers, is focused on the development of the Human Development Index (HDI) which is released annually by the United Nation Development Program (UNDP) as an institution under the auspices of the United Nations (UN). The development of human resources development or the human development index has often received various criticisms and suggestions, however, all parties agree that human resource development is the key to successful development both at the national and regional levels, especially those related to the development of community welfare, especially in the social and economic fields. As Oliver 
Holmes wrote in Irwan Abdullah (2010: 82) that The greatest tragedy in America is not the destruction of our national resources, thougt that tragedy is great. The truly great tragedy is the destruction of our human resources by our failure to fully utilize our abilities, which means that most men and womwn go their graves with their music still in them.

Holmes's view emphasizes that human resources are the key to the success of a country, and ignoring this aspect is a big mistake. Therefore, improving the quality of human development is not only the task of the government, but also needs to be supported by the role of the community and the business world to make systematic and integrated efforts in all aspects of life including education, health, economy, politics, social and culture. The human development approach focuses more on people's choices to live in freedom and dignity. Human development includes all issues that exist in society, from economic growth, employment, trade, and social values that exist in society.

The preamble to the 4th paragraph of the 1945 Constitution of the Republic of Indonesia (UUD) mandated that one of the objectives of the establishment of the state government of the Republic of Indonesia was to promote general welfare and the intellectual life of the nation which would be implemented based on the values contained in the -5 (five) precepts in Pancasila. The form of implementation of this mandate is carried out through the development of human resources in Indonesia which is known as the "Human Development Index" (IPM). As a form of government responsibility for human development in Indonesia, various strategic policies were issued in the form of regulations that regulate technically starting from planning, implementation to evaluating the value of the human development index in Indonesia because human development is considered to have a very important role in realizing lofty ideals. Upholding the Unitary State of the Republic of Indonesia (NKRI).

The concept of HDI was first introduced by UNDP in 1990 where the HDI was considered an expansion of options for the population. HDI can be seen as an effort to increase the "range of options" as well as as a tool to achieve a more decent standard of living. From another point of view, human development can also be defined as a change for the better for the level of education, health and the economy through the use of knowledge and skills. This definition provides a broader meaning than economic development which focuses more on meeting basic needs and economic growth to achieve social welfare. According to a report released by the Central Bureau of Statistics in the Analysis of the Achievement of the Bekasi District Human Development Index in 2018 (2018: 3) the human development paradigm contains 4 (four) main components, namely:

1. Productivity, namely humans must have the ability to increase their productivity and participate fully in efforts to earn income and employment. When linked with economic development, this definition interprets that economic development is one part of human development.

2. Equity / Equity, that is, everyone must have access to equal opportunities. All problems and obstacles to economic and political opportunities must be removed so that people / society can actively participate in obtaining the benefits of these opportunities. 
3. Continuity, namely access to opportunities / opportunities must be available not only for the current generation but also for future generations where all forms of capital, whether physical, human or environmental, must be renewable.

4. Empowerment, namely development must be carried out by the community and not only for them but for all existing stakeholders. The community must play an active role in the decision-making and processes that affect their lives.

Based on the human development paradigm put forward by BPS, a conclusion can be drawn that human development includes productivity, that is, someone must be able to produce something from what he has done in various aspects of life, equity / equity, that is, everyone has the same opportunity to achieve goals. Life, sustainable, namely carried out continuously (not breaking up in a certain period) and empowerment, namely an effort to rise and independently build life in an effort to achieve life goals.

In measuring the level of fulfillment of these 4 (four) main components of human development, UNDP compiles a composite index consisting of 3 (three) main indicators, namely life expectancy, adult literacy rate, average length of schooling, and purchasing power of people is a measure of income that has been synergized with public purchasing power parity. This is in line with what was released by BPS in the Analysis of the Achievement of the Bekasi District Human Development Index in 2018 (2018: 10) that the Human Development Index indicator is a composite index that includes three areas of human development that are considered very basic, namely age. life (longevity), knowledge (knowledge) and a decent standard of living (decent living). This indicator does not only take into account physical quality which can be seen from life expectancy, but also measures non-physical quality (knowledge) as indicated by the expected length of schooling and the average length of schooling and takes into account the economic capacity of the community in an area as indicated by purchasing power parity index (ppp).

West Java Province is the province with the largest population in Indonesia. Based on statistical data in 2018, the population of West Java Province was 45,161,325 people. This shows that 20 percent of Indonesia's population is in West Java. The population of West Java Province is so large, it creates its own problems in the development of human resources in West Java, especially regarding the development of HDI. The vast area and the large population of West Java cause quite high social problems, especially in the provision of services for basic community needs in the form of education and health as well as improving the standard of living of the people of West Java. The value of West Java HDI during the 2013-2018 period was not very encouraging, because its realization was always below the National HDI.

Table 1. West Java Province Human Development Index 2013-2018

\begin{tabular}{|l|c|c|c|c|c|c|}
\hline \multirow{2}{*}{\multicolumn{1}{|c|}{ Description }} & \multicolumn{7}{c|}{ HDI } \\
\cline { 2 - 7 } & 2013 & 2014 & 2015 & 2016 & 2017 & $2018^{*}$ \\
\hline West Java Province & 68,25 & 68,80 & 69,50 & 70,05 & 70,69 & 70,99 \\
\hline National & 68,31 & 68,90 & 69,55 & 70,18 & 70,81 & 71,33 \\
\hline
\end{tabular}


Source: West Java Provincial Government Work Plan 2020 (2019: II-49).

The national HDI position of West Java has not yet entered the top 10 (ten) ranks, which has only been in positions 12 to 10 during the last 5 (five) years. Even though West Java Province has a fairly good economic potential supported by the industrial sector and the agricultural sector, plus the largest contribution of the island's GRDP to the national Gross Domestic Product (GDP) comes from Java Island, which is 58.5 percent in 2016-2017 growth of 5.6 percent.

The IPM value of West Java is a contribution from the IPM of districts / cities in West Java Province, one of which is Bekasi Regency. In general, the HDI value in Bekasi Regency increases every year. However, the increase in the HDI value has not been able to increase the HDI position of Bekasi Regency at the West Java Province level. During the 2012-2017 period, the HDI position of Bekasi Regency was still in the same position, namely in the 8 (eight) rank of 27 (twenty-seven) districts / cities in West Java Province. The following is a table of the HDI for districts / cities in West Java up to 2017 as follows:

Table 2. HDI of District/City in West Java Province year 2012-2017

\begin{tabular}{|l|l|l|l|l|l|l|l|}
\hline \multirow{2}{*}{ NO } & District/City & \multicolumn{2}{l}{ HDI } \\
\cline { 3 - 8 } & & $\mathbf{2 0 1 2}$ & $\mathbf{2 0 1 3}$ & $\mathbf{2 0 1 4}$ & $\mathbf{2 0 1 5}$ & $\mathbf{2 0 1 6}$ & $\mathbf{2 0 1 7}$ \\
\hline 1 & District Bogor & 65,66 & 66,74 & 67,36 & 67,77 & 68,32 & 69,13 \\
\hline 2 & District Sukabumi & 62,27 & 63,63 & 64,07 & 64,44 & 65,13 & 65,49 \\
\hline 3 & District Cianjur & 60,28 & 61,68 & 62,08 & 62,42 & 62,92 & 63,70 \\
\hline 4 & District Bandung & 68,13 & 68,58 & 69,06 & 70,05 & 70,69 & 71,02 \\
\hline 5 & District Garut & 61,04 & 61,67 & 62,23 & 63,21 & 63,64 & 64,52 \\
\hline 6 & District Tasikmalaya & 61,69 & 62,40 & 62,79 & 63,17 & 63,57 & 64,14 \\
\hline 7 & District Ciamis & 66,29 & 67,20 & 67,64 & 68,02 & 68,45 & 68,87 \\
\hline 8 & District Kuningan & 65,60 & 66,16 & 66,63 & 67,19 & 67,51 & 67,78 \\
\hline 9 & District Cirebon & 64,48 & 65,06 & 65,53 & 66,07 & 66,70 & 67,39 \\
\hline 10 & District Majalengka & 63,13 & 63,71 & 64,07 & 64,75 & 65,25 & 65,92 \\
\hline 11 & District Sumedang & 67,36 & 68,47 & 68,76 & 69,29 & 69,45 & 70,07 \\
\hline 12 & District Indramayu & 62,09 & 62,98 & 63,55 & 64,36 & 64,78 & 65,58 \\
\hline 13 & District Subang & 64,86 & 65,48 & 65,80 & 66,52 & 67,14 & 67,73 \\
\hline 14 & District Purwakarta & 66,30 & 67,09 & 67,32 & 67,84 & 68,56 & 69,28 \\
\hline 15 & District Karawang & 65,97 & 66,61 & 67,08 & 67,66 & 68,19 & 69,17 \\
\hline $\mathbf{1 6}$ & District Bekasi & $\mathbf{6 9 , 3 8}$ & $\mathbf{7 0 , 0 9}$ & $\mathbf{7 0 , 5 1}$ & $\mathbf{7 1 , 1 9}$ & $\mathbf{7 1 , 8 3}$ & $\mathbf{7 2 , 6 3}$ \\
\hline 17 & District Bandung Barat & 63,17 & 63,93 & 64,27 & 65,23 & 65,81 & 66,63 \\
\hline 18 & District Pangandaran & - & 64,73 & 65,29 & 65,62 & 65,79 & 66,60 \\
\hline 19 & City Bogor & 72,25 & 72,86 & 73,10 & 73,65 & 74,50 & 75,16 \\
\hline 20 & City Sukabumi & 69,74 & 70,81 & 71,19 & 71,84 & 72,33 & 73,03 \\
\hline 21 & City Bandung & 78,30 & 78,55 & 78,98 & 79,67 & 80,13 & 80,31 \\
\hline 22 & City Cirebon & 71,97 & 72,27 & 72,93 & 73,34 & 73,70 & 74,00 \\
\hline 23 & City Bekasi & 77,71 & 78,63 & 78,84 & 79,63 & 79,95 & 80,30 \\
\hline
\end{tabular}




\begin{tabular}{|l|l|l|l|l|l|l|l|}
\hline \multirow{2}{*}{ NO } & District/City & \multicolumn{3}{l|}{ HDI } \\
\cline { 3 - 8 } & & $\mathbf{2 0 1 2}$ & $\mathbf{2 0 1 3}$ & $\mathbf{2 0 1 4}$ & $\mathbf{2 0 1 5}$ & $\mathbf{2 0 1 6}$ & $\mathbf{2 0 1 7}$ \\
\hline 24 & City Depok & 77,28 & 78,27 & 78,58 & 79,11 & 79,60 & 79,83 \\
\hline 25 & City Cimahi & 74,99 & 75,85 & 76,06 & 76,42 & 76,69 & 76,95 \\
\hline 26 & City Tasikmalaya & 67,84 & 68,63 & 69,04 & 69,99 & 70,58 & 71,51 \\
\hline 27 & City Banjar & 67,53 & 68,01 & 68,34 & 69,31 & 70,09 & 70,79 \\
\hline
\end{tabular}

Source: West Java Province Central Statistics Agency, 2018.

Based on these data, of course increasing the HDI value is homework for the Bekasi Regency Government to make breakthroughs and innovations more optimally, given the very strategic position of Bekasi Regency which is one of the National Activity Centers (PKN) which is located close to the center of government, included in the JABODETABEKPUNJUR development area and is the largest industrial area in Southeast Asia. Not to mention the contribution of the Gross Regional Domestic Product (PDRB) of Bekasi Regency to the PDRB value of West Java Province which is always in the top position. This could at least be a lever of the HDI position of Bekasi Regency because GRDP is related to per capita income. Macroeconomic growth, economic structure, per capita income and other economic indicators are indicators of measuring the performance of economic development in a region. Furthermore, according to BPS (2008: 1) in the Economic Development Profile of Bekasi District according to the 2018 Usage Component, it is stated that GRDP is one of the macro indicators to measure the economic development performance of an area in a certain period. Thus, the research question is why the 2012-2017 HDI target for Bekasi Regency was not achieved? To answer this problem, the Strategic Management theory proposed by Wheelen and Hunger (2012) is used which includes variables Environmental Scanning, Strategy Formulation, Strategy Implementation and Evaluation and Control. However, this article will focus on aspects of the Environmental Scanning analysis which include External Opportunities and Threats.

\section{Method}

The approach used in this research is a qualitative method, according to John W Creswell (2016: 4-5). Qualitative research is a method used to explore the meaning that certain groups think comes from social or human problems. This qualitative research process is carried out by asking questions and procedures, collecting specific data from informants, analyzing data inductively starting from specific themes to general themes, and interpreting the meaning of the data. a flexible structure or framework. Researchers who use qualitative research methods must apply an inductive research perspective, focus on individual meanings and translate the complexity of a problem. Meanwhile, according to Wolcott (2009: 11), the qualitative approach is based on the preparation of analysis tables obtained from the results of interview data and projecting the interview data. In research, some data is needed based on in-depth interviews, documents, statistical data and other supporting documents. In-depth interviews will be conducted with several informants who are determined in accordance with the research objectives. Based on the results of the interview, verification and digging will be carried out in more depth of the existing facts from the information and documents obtained so that the opinions and views of the informants can be known through face to face with the informants that have been determined. 


\section{Result and Discussion}

\section{External Opportunities and Threats}

Environmental observation is a series of assessments and monitoring to identify opportunities and challenges for the organization's environment to achieve its goals. Observation of the environment aims to anticipate problems in the organizational environment so that policies can be taken to achieve organizational goals. In an effort to produce environmental observations optimally, it is necessary to carry out an environmental analysis which will be used by strategic planners in determining opportunities or threats.

a. Natural Environment

The external environment is a very strategic part of achieving organizational goals. The degree of external environment also varies depending on the condition of the object which will be influenced by the external environment itself. As noted by O'Regan, $\mathrm{N} \&$ Ghobadian, A (2005: 69):

The importance of the external environment varies, depending on whether the firm operates in a stable or turbulent market. The more complex or dynamic the environment, the greater the degree of uncertainty. Consequently, in a dynamic market, greater emphasis is given to the external environment.

Opinion O'Regan \& Ghobadian, A emphasized that the external environment has varying degrees of importance depending on the stability of the companies operating in the market. The level of uncertainty increases when the environment becomes more dynamic or complex. For this reason, greater emphasis is placed on the external environment for dynamic markets. In the context of governance in Bekasi Regency, observations of the external environment must be carried out to provide an assessment of the variables that affect the HDI planning management strategy in Bekasi Regency.

Empirically, as reported in Bekasi Regency in 2019, Bekasi Regency is passed by 18 (eighteen) rivers / streams including Kali Ulu, Cikarang, Cikedokan, Sadang, Cibeureum, Ciherang, Cilemahabang, Jaeran, Jambe, Sasak Jarang, Cipamingkis, Cibeet, CBL, Bekasi, Pisangan, Blencong, Babakan, Cikadu. The rivers are used for irrigation, the network of raw water for drinking water, as well as for industrial and household purposes. Apart from rivers, there are also 14 (fourteen) lakes in Bekasi Regency, namely: Situ Bojongmangu, Burangkeng, Ceper, Ciantra, Cibereum, Cibungur, Cipalahlar, Lengsir, Liang Maung, Rawa Binong, Taman, Tegal Abidin, Pagadungan, and Been. This geographical condition causes floods to often hit Bekasi Regency. The following shows data on disasters that occurred in Bekasi Regency during the period 2012-2017.

Table 3. Natural Disaster Incidents in Bekasi Regency 2012-2017

\begin{tabular}{|c|c|c|c|c|}
\hline \multirow{2}{*}{ Year } & \multicolumn{4}{|c|}{ Type of Disaster } \\
\cline { 2 - 5 } & Flood & Landslide & Tornado & Drought \\
\hline $\mathbf{1}$ & $\mathbf{2}$ & $\mathbf{3}$ & $\mathbf{4}$ & $\mathbf{5}$ \\
\hline 2012 & 13 & 4 & 11 & 11 \\
\hline 2013 & 47 & 2 & 12 & 12 \\
\hline 2014 & 20 & 1 & 11 & 7 \\
\hline 2015 & 5 & 1 & - & 7 \\
\hline 2016 & 137 & 3 & 3 & 31 \\
\hline 2017 & 8 & - & 2 & 9 \\
\hline
\end{tabular}


Source: Local Disaster Management Agency, 2018.

If you look at the table above, directly or indirectly, disasters that occur in Bekasi Regency can interfere with the process of achieving HDI which will prevent students from attending school, hamper the economy in the absence of an operating market and obstruct the community from going to health facilities due to the limited number of modes of transportation disaster happened. Not only the aspects of natural disasters above, empirically, Bekasi District is also divided into 2 (two) with different characteristics, namely the northern and southern regions. The northern area, which has lowland characteristics and is close to Jakarta Bay, will always be associated with potential impediments to achieving the district's HDI target due to floods, high tides and river overflows that could strike at any time.

On the other hand, the southern part of Bekasi Regency is dominated by hills and highlands. Geographically, the southern part of Bekasi Regency is not too problematic because the conditions of education, health and economic support infrastructure are relatively well-maintained. The geographical conditions of the southern part of Bekasi Regency are more favorable when compared to the geographical conditions of the northern Bekasi Regency. For this reason, in terms of growth and economy, the southern part of Bekasi Regency is growing and developing faster. Likewise, in the field of education and health, the available access is also more complete, easier and more maintained.

Not only in the soil structure, it appears in the interview quotation above that there are weaknesses in the form of potential landslides and floods that can hamper community activities. It appears to be supported by the condition of the soil structure owned by Bekasi Regency such as valleys, mountain slopes, coastal areas and land areas. All these areas are inhabited by people who must get services from the Bekasi Regency government. The data on the number of villages in Bekasi Regency based on land type can be seen as follows:

Table 4. Number of Villages in Bekasi Regency based on Land Type

\begin{tabular}{|c|l|l|}
\hline No & \multicolumn{1}{|c|}{ Location } & \multicolumn{1}{c|}{ Total } \\
\hline 1 & Village in watershed & 0 \\
\hline 2 & Village in Slope & 6 \\
\hline 3 & Village in Plain & 172 \\
\hline 4 & Village in Coastal & 9 \\
\hline
\end{tabular}

Source: Local Mid-Term Planning Report, 2018.

It can be seen in the table above that almost all villages are in plain areas with 15 villages in slope and coastal villages. Although there are no villages in the vicinity of the basin of the watershed (DAS), this area can also be an obstacle in achieving HDI in Bekasi District. This is due to the geographical position of Bekasi Regency which is traversed by the Citarum Watershed, which is one of the sources of clean water. As with the development report of BODEBEKKARPUR, the Citarum watershed has the potential to threaten the availability of clean water and raw water for agriculture and energy (PLTA). 
b. Social Environment

The social environment is a part of the external environment that has long-term impacts. The social environment consists of several aspects consisting of economic, political and legal, technological and socio-cultural forces. According to Wheleen and Hunger (2012: 99) there are 4 (four) factors of environmental forces that affect the industry, namely:

1. Economic forces that regulate the exchange of materials, money, energy, and information.

2. Technological forces that generate problem-solving inventions.

3. Political-legal forces that allocate power and provide constraining and protecting laws and regulations.

4. Sociocultural forces that regulate the values, mores, and customs of society.

Economic pressure factors can hinder the achievement of regional HDI because this factor is a little difficult to control. This is because national economic conditions can affect regional economic conditions. The economy of Bekasi Regency has a fairly good contribution to the national economy and in West Java Province. This is as expressed by the Bekasi Regent that "Bekasi Regency is the largest contributor to West Java's GRDP, which is contributing approximately 15 percent".

The economic growth that occurs in Bekasi Regency is not directly proportional to the increase in the community's economy so that indirectly its contribution to HDI is not optimal. This becomes evident when the inflation that has occurred in the last 3 (three) years has resulted in an increase in the price of goods, an increase in the price of fuel and others. The high output of the industrial sector has resulted in a high GRDP figure of Bekasi Regency, although in fact there are still many Bekasi Regency people who live below the poverty line and have low purchasing power. In real terms, the high PDRB value of ADHB Bekasi Regency is caused by the role of the processing industry in Bekasi Regency. However, the results are not fully enjoyed by the people of Bekasi Regency because many of the products from the processing industry are exported. Bekasi Regency's exports are recorded to increase every year although the increase is not too significant, starting at Rp. 1,903.29 USD in 2012 and 1,906.44 USD in 2017. This shows that the multiplier effect of the industry has not been sufficient to provide a positive value for the economy of the people of Bekasi Regency. In other words, the high GRDP in Bekasi Regency is not contributed from the real sector (such as the agricultural, trade, fishery and marine sectors, services) but from the manufacturing sector which is growing and developing due to the existence of an industrial area in Bekasi Regency.

Inflation is one of the components forming the strength of the economy both at the central and regional levels, where inflation is an increase in prices in average (aggregate), while a decrease in prices on average is called deflation. During the period 2012-2017, the highest inflation rate occurred in 2013, which was 9.71 percent, then decreased slowly in 2014 to 8.13 percent. The high inflation in that year was due to the increase in the price of fuel oil (BBM). At the same time, the increase in the prices of various goods and services is also shown by the percentage change in the PDRB deflator and the Consumer Price Index (CPI). The price increase indicated by the CPI was lower, namely by 3.80 percent compared to the percentage change in PDRB deflator of 1.80 percent. This means that in 2017 the rate of 
increase in prices paid by the government / companies was lower than the rate of increase in prices paid by households to consume a number of goods / services. Meanwhile, for 2015 to 2017, inflation in Bekasi Regency can be said to be stable. High inflation results in low purchasing power. However, inflation that is too low can also weaken producers because it results in the accumulation of goods produced due to a decrease in demand for these goods. In general, inflation that occurred in Bekasi Regency during the period 2012-2017 was relatively stable, meaning that it was quite conducive for economic activity in Bekasi Regency. Conducive economic activity certainly provides fresh opportunities for business and will ultimately lead to an increase in the people's economy. With a good economic condition, it can encourage people to fulfill the need for primary basic services in the form of education and health. Economic conducivity in Bekasi Regency does not guarantee that the economic growth of Bekasi Regency will increase every year. Based on data obtained from BPS Bekasi Regency, the economic growth of Bekasi Regency fluctuates during 2012-2017, namely 6.53 percent in 2012, decreased to 6.23 percent in 2013, decreased again to 5.88 percent in 2014 , fell steadily to 4.66 percent in 2015, then increased slowly in 2016 to 4.99 percent and continued to grow to 5.78 percent in 2017.

Political interaction between the Bekasi district government and the DPRD is needed to produce optimal regional policies. In the administration of Bekasi Regency government, there is political interaction between the Regional Government and the DPRD. The results of this political interaction are in the form of regional law products including regional regulations, the number of which can be seen in the following figure:

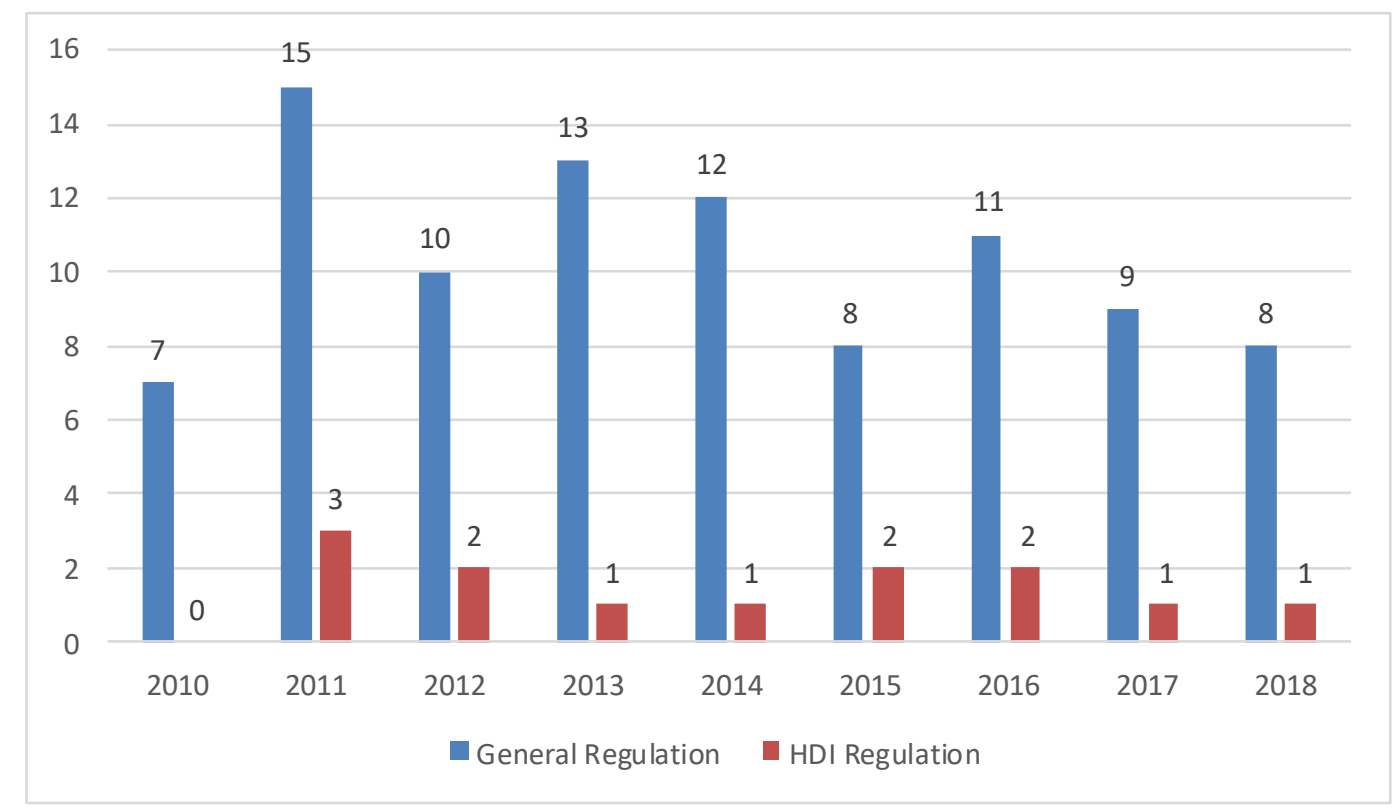

Graph 1. Regional Regulations Produced in 2010-2018

Source: Local Agency of Law, 2019.

Each year, specifically in the process of planning, budgeting, and evaluating regional development performance, there are 7 (seven) discussions, namely the musrenbang process (village, sub-district and district), discussion of KUA and PPAS APBD both pure and 
amendments, discussion of RAPBD both pure changes, LKPJ and APBD Accountability Report.

The development of HDI in Bekasi District needs to be supported by information technology. If previously education, health and economic activities were still carried out manually, with the development of information technology these activities can be done online with various facilities and facilities. Senn (1998: 12) states that "Implementing strategy is often referred to as the" action stage "of strategic management. Implementing the strategy has the intention of mobilizing employees and managers to translate the strategy that has been formulated into action".

In general, the main problem in the use of information technology in Bekasi Regency is the limited facilities and infrastructure to support information technology ranging from networks, hardware to software. The availability of the information technology network required is the availability of internet services to operate equipment that utilizes information technology. During the 2012-2013 period, information technology infrastructure had not been built in Bekasi District, only then in 2015 a budget was allocated for the development of information technology in the form of fiber optic networks that serve schools and throughout the village.

Socioculturalism is an aspect that greatly affects the environment, as previously reviewed is that the measure of sociocultural strength consists of lifestyle, career expectations, consumer activity, family formation, population growth and age distribution, regional shifts in population, life expectancy and birth rates.

The weakness of the socio-cultural aspect in Bekasi Regency, especially in increasing the HDI value, is that it does not pay attention to the needs of women both from the aspects of education, health, and improving the economy. This can be seen from the GAP between the HDI and the IPG, which on average each year have a difference of up to 2 (two) digits. Based on data from BPS Bekasi Regency, in 2012 there was a difference of 16.06 then in 2013 there was a difference of 15.74, in 2014 the difference was 15.71, in 2015 it was 16.29 and in 2017 the difference was 15.37. The two-digit difference indicates the large development gap between men and women in Bekasi District.

Based on the data on the components of the HDI for the education index, during the period 2012-2017 the boys' expectation of schooling was higher than that of women, namely in 2012 men were 11.38 years, women were 10.97 years; in 2013 male 11.81 years old, female 11.24 years old; in 2014 male 11.96 years old, female 11.51 years old; in 2015 male 11.99 years old, female 11.48 years old; and in 2017 male 11.6 years, female 11.65 years. If the average value is taken, the male expected length of schooling is 11.95 years, while the average length of schooling for girls is 11.57 years, a difference of 0.38 years. From the aspect of the expected length of schooling, there is no significant difference.

Based on the aspect of the average length of schooling, the conditions are still the same as the expectation for the length of schooling, which is higher for men than for women. In 2012, the average length of schooling for boys in 2012 was 8.95 years, for girls 7.53 years; in 2013 male 9,01 years, female 7,72 years; in 2014 male was 9.08 years, female was 7.76 years; in 
2015 it was men 9.26 years, women 8.05 years, and in 2017 men 9.46 years, women 8.17 years. If the average school year is calculated, the average length of school for boys is 9.2 years, while for girls it is 7.8 years. This means that there is a 2-year gap between the average length of school for boys and girls. This gap is quite large because the difference is more than 2 digits.

\section{c. Task Environment}

In government administration, Wheelen and Hunger's theory can be implemented, where this theory directs the idea that company activities are continually assessed by stakeholder groups in order to determine company performance, where these stakeholder groups will influence the organization to improve the situation towards a better direction. This can be reflected in the organizations / agencies that run local governments which in the context of this study carry out regional policies in the field of human development which are divided into the fields of education, health and the economy (increasing purchasing power).

Based on the theory put forward by Wheelen and Hunger, in the context of government administration, what is meant by the work environment is all stakeholders affected by or participating in policy formulation, policy implementation and control and evaluation.

In general, the work environment that takes part in the achievement of the HDI in Bekasi District provides positive support for the Bekasi Regency government efforts to increase the HDI value. The work environment consists of vertical agencies, DPRD, the business world, community groups and the public.

The internal work environment that is not conducive has resulted in the ranks of the Bekasi District Education Office facing legal issues, as stated by the Bekasi District Inspector. It's not the organization that's always wrong. Because the funds are large, the risk is also great. Departing from this opinion, requires the Bekasi District Education Office to always create a conducive internal work environment which has implications for the external work environment consisting of DPRD, vertical agencies, communities, business world and non-governmental organization groups.

Another aspect that is one of the sectors that has contributed to increasing the purchasing power of the people of Bekasi Regency is the agricultural sector, in which the agricultural sector is one of the sectors that opens up quite a lot of jobs. The same is the case with other sectors as previously described that has a work environment that is quite conducive, especially the work environment which includes vertical agencies, DPRD, the business world, as well as farmer groups in Bekasi Regency. However, there is a separate problem related to the external work environment of the agricultural sector, namely the existing farmer groups do not have legality as mandated by the Minister of Home Affairs Regulation Number 32 of 2011 concerning Guidelines for Providing Grants and Social Assistance sourced from the Regional Revenue and Expenditure Budget. Article 7 paragraph (1) states that the conditions for grants to the community can be given on the condition that they have clear management and are domiciled in the administrative area concerned. 


\section{Internal Strong and Weaknesses}

According to Wheelen \& Hunger, internal components consist of structural, cultural, and resource components.

\section{a. Structure}

Organizational structure is needed as a range of control assignments in an organization. The organizational structure focuses on the arrangement of the division of tasks that will be given to the authorities and functions, so that it does not merely talk about the building where it works. Organizational goals to be achieved will be influenced by the existing structure, because the structure divides, classifies and coordinates each job or task formally and systematically to all members of the organization which is developed and directed continuously to achieve organizational goals. There are several forms of schemes that are described to make it easier to understand the form of an organizational structure, ranging from onigram to chart forms which provide information on organizational relationships both vertically and horizontally across structural levels and between individuals.

During the period 2012-2017 the organizational structure of the Bekasi Regency regional apparatus has undergone 3 (three) changes, namely, based on Bekasi Regency Regulation Number 4 of 2011, Bekasi Regency Regional Regulation Number 8 of 2014 and Bekasi Regency Regional Regulation Number 6 of 2016. Of the 3 (three) changes, the most basic changes occurred in Regional Regulation Number 6 of 2016, because this Regional Regulation was born as a follow-up to the enactment of Law Number 23 of 2014 concerning Regional Government and Government Regulation Number 18 of 2016 concerning Regional Devices.

Such organizational changes often occur, causing some program activities to be somewhat hampered, due to adjustments to the main tasks and functions of Regional Apparatus. As stated by the Head of the Bekasi Regency Regional Development Planning Agency. Changes in the organizational structure that occurred in the 2012-2017 period had an impact on several regional instruments. The organizational structure problem occurred in the Education Office in 2012-2014, namely the workload was too heavy in one of the sections in the agency, namely Kindergarten, Elementary and Junior High Schools, Basic Education Technical Personnel Section and the Basic Education Quality Control Section, which both handles SD and SMP with a large number of SD and SMP in Bekasi District. As stated by the Head of the Bekasi District Education Office: "One more thing, the organizational structure that is formed should not be disproportionate, because later there will be units that are overloaded with work or vice versa". The issue of workload reappeared in 2014-2016, namely the loss of educational facilities and infrastructure, because the workload handled by the Elementary School and Junior High Schools was quite heavy because they had to also handle learning facilities that were previously carried out in separate fields.

b. Culture

In practice, the Head of the Education Office and the Head of the Health Office agreed to give views related to organizational culture that currently work culture and work ethic of 
employees still need to be improved considering the conditions of employees in Bekasi Regency are still "lazy" to work. This is because employees do not have the initiative to do a job or work creativity if there is no instruction from the leadership. In other words, employees in general are still waiting for leadership directions to do a job. In addition, employees who are old have not been able to adapt their work to existing technological developments. This deficiency seems to be felt by the employee concerned so that the employee is currently only waiting for his return hour. The form of written rules regarding Work Culture also did not exist during the 2012-2017 period. So that if a work culture is formed, it is solely because of the level of awareness that each individual has. Regulations on new work culture were enacted in 2019 through Bekasi Regent Regulation Number 31 of 2019 concerning Work Culture in the Bekasi Regency Government where it is said that the work culture "... is intended as one of the instruments of bureaucratic reform which is carried out systematically through excavation, formulation, and implementation. The value of Work Culture into a pattern of thought, pattern of behavior and pattern of action consistently, consequently and continuously in the context of smoothness, effectiveness and results in carrying out the tasks of government administration, development and service to the community ".

Based on the description above, it appears that the organizational work culture has not been built institutionally in Bekasi Regency in 2012-2017 because it is not fully understood by employees which can hinder the performance of the organization, especially the Education and Health Services and other relevant regional apparatus in achieving the HDI targets for Bekasi Regency.

\section{c. Resources}

The majority of employees in Bekasi Regency are undergraduate and high school graduates. S1 / D4 graduates if associated with the Regulation of the Minister of State Apparatus Empowerment and Bureaucratic Reform Number 41 of 2018 concerning the Nomenclature of Implementing Positions for Civil Servants in the Scope of Government Agencies are requirements for positions as executing analyst, data processing, data manager, and others. While high school graduates in the regulation are technicians, inspectors, administrators, and others. The table above also shows that on average, officials from supervisors to JPT based on education level, the majority have an undergraduate level. So that if it is reduced by officials, the number of executive positions with an S1 education is smaller than that of high school graduates.

The relationship between these conditions and the Regulation of the Minister of State Apparatus Empowerment Number 41 of 2018 concerning the Nomenclature of Executing Positions for Civil Servants in Government Agencies is that the profile of civil servants as executors is that the majority have high school education while on the other hand the need for employees who have high qualifications is very high so that conditions this can be a stumbling block in improving organizational performance. This was admitted by the Bekasi Regent who said that:

In terms of quantity, the human resources of the apparatus within the Bekasi Regency 
Government are adequate (excluding education and health personnel), but in terms of quality it is still lacking. The number of civil servant teachers and doctors, midwives and other medical personnel is still insufficient, so we still have to be assisted by honorary teachers, who up to now number around 9,000 people. It is hoped that in the future it is necessary to increase the competence of apparatus resources, especially in agencies that are obliged to increase the HDI in Bekasi Regency (especially in the Education and Health Office).

Based on the quotation above, it appears that employees in Bekasi Regency have met in quantity but are still lacking in quality. So that the skills and knowledge possessed by civil servants can affect the level of achievement of the organizational targets, in this case the achievement of HDI for the people of Bekasi Regency.

In human development in Bekasi Regency, what is needed is not only human resources, but also facilities and infrastructure that support the work of Regional Apparatus within the Bekasi Regency Government which are used to accelerate the achievement of goals. The facilities and infrastructure referred to by Whelen and Hunger's theory are factory facilities in a functional area. If it is related to the availability of facilities and infrastructure that support the achievement of HDI in Bekasi Regency, it can be seen from the facilities and infrastructure owned by Regional Apparatus, particularly those related to the achievement of HDI.

When viewed from the availability of existing facilities and infrastructure, especially in regional apparatus related to the achievement of HDI in Bekasi Regency, the number of educational and health facilities and infrastructure is still limited. The number of buildings owned by the Education Office was 326 school buildings in 2012, 123 school buildings and 82 library buildings in 2013, 125 school buildings and an additional 21 library buildings in 2014, 123 school buildings and 5 additional library buildings in 2015 and 116 school buildings and the addition of 3 library buildings in 2016. This condition is of course not comparable to the number of schools in Bekasi Regency, namely 708 public elementary schools, 96 public junior high schools, 44 public high schools and 15 public vocational schools. The inadequate condition of the school building has resulted in the imposition of 3 to 4 study groups for SD every day, and 2 (two) study groups for SMP and SMA.

\section{Closing}

The factors that cause the Human Development Index target not to be achieved in Bekasi Regency are: a) Environment and Natural Condition of Bekasi Regency; b) high inflation that occurred in 3 (three) consecutive years; c) the multiplier effect from the existence of the industry is not sufficient to provide a positive value for the economy of the Bekasi Regency community. d) a patriarchal culture is still strong in Bekasi Regency; e) The lack of local regulations issued regarding the achievement of HDI; f) Availability of technology and information facilities is still limited; g) Inconsistent budget allocations for programs resulted in unsustainable program implementation. h) Changes in the Organizational Structure of Regional Apparatus due to Government Policies.

Strategic planning from internal factors in the form of fulfilling human resource needs, both 
human resources and supporting facilities and infrastructure for work activities, needs to be considered both in terms of quantity and quality. From the aspect of human resources, it is necessary to recalculate the workload of the organization so that the proportionate needs of personnel can be obtained. Likewise from the aspect of competence, it is necessary to add employees with adequate competence. Meanwhile, from the aspect of the availability of facilities and infrastructure, it is necessary to map the needs for facilities and infrastructure in accordance with the needs of regional apparatus.

\section{Reference}

Creswell, J. W. (2016). Research design: pendekatan metode kualitatif, kuantitatif, dan campuran. Yogyakarta: Pustaka Pelajar.

David, F. R., \& David, F. R. (2013). Strategic management: Concepts and cases: A competitive advantage approach. Pearson.

Djaenuri, M. A. (2012). Hubungan keuangan pusat-daerah: elemen-elemen penting hubungan keuangan pusat-daerah. Ghalia Indonesia.

Dunn, W. N. (2003). Terjemahan: Public Policy Analysis: An Introduction (Pengantar Analisis Kebijakan Publik), Edisi Kedua, Penerjemah: S. Wibawa, D. Asitadani, A. Heruanto H. E. A. Purwanto. Yogyakarta: Gadjah Mada University Press.

Edwards, III., \& George, C. (1980). Implementing Public Policy. Public Policy Studies.

Effendy, K. (2010). Memadukan Metode Kuantitatif Kualitatif. Bandung: CV. Indra Prahasta.

Faisal, S. (2005). Format-Format Penelitian. Raja Grafindo Persada, Jakarta.

Freeman, R. Edward and John McVea. n.d. A Stakeholder Approach to Strategic Management. Working Paper No. 01-02. The Darden Scholl: University of Virginia.

Haming, M., \& dan Mahfud, N. (2011). Manajemen Produksi Modern (Operasi Manufaktur dan Jasa) Buku 1. Jakarta : Bumi Aksara.

Politzer, G., \& Baratgin, J. (2016). Deductive schemas with uncertain premises using qualitative probability expressions. Thinking \& Reasoning, 22(1), 78-98. https://doi.org/10.1080/13546783.2015.1052561

Sastrapratedja, M., Riberu, J., \& Parera, F. M. (1986). Menguak mitos-mitos pembangunan: telaah etis dan kritis. Gramedia.

Van Meter, D. S., \& Van Horn, C. E. (1975). The policy implementation process: A conceptual framework. Administration \& Society, 6(4), 445-488. https://doi.org/10.1177/009539977500600404

Wheelen, T. L., \& Hunger, J. D.,(2012). Strategic Management and Business Policy (Toward Global Sustainability). USA : Pearson Education, Inc, Publishing as Prentice Hall.

Yolanda, Y. (2017). Analysis of factors affecting inflation and its impact on human development index and poverty in Indonesia. https://doi.org/10.35808/ersj/873 


\section{Copyright Disclaimer}

Copyright for this article is retained by the author(s), with first publication rights granted to the journal.

This is an open-access article distributed under the terms and conditions of the Creative Commons Attribution license (http://creativecommons.org/licenses/by/4.0/). 